\section{Total serum vitamin $C$ concentration in pregnant women: implications for a healthy pregnancy}

\author{
Concentração total de vitamina C na \\ gestante: implicações para uma gestação \\ saudável
}

Garba Ibrahim Hassan 1

Amodu Bala Onu 2

1,2 Chemistry Programme. School of Science. Abubakar Tafawa Balewa University. PMB 0248 Bauchi, Nigeria. E-mail: ihgarba2002@yahoo.com

\begin{abstract}
Objectives: total serum vitamin C (L-ascorbic acid) concentration was measured in 90 pregnant women, 30 in each trimester (age range 18-35 years) and a control group of age-matched non-pregnant women.

Methods: total serum vitamin $C$ concentration was measured using the 2.4-dinitrophenylhydrazine method which involves the conversion of vitamin $C$ to dehydroascorbic acid in the presence of copper (II) ions and subsequent measurement of the resulting bishydrazone at $540 \mathrm{~nm}$.

Results: the total vitamin $C$ concentration in the first trimester was $2.55 \pm 0.82 \mathrm{mg} / \mathrm{dl}$ and $2.32 \pm 0.40$ $\mathrm{mg} / \mathrm{dl}$ and $0.77 \pm 0.10 \mathrm{mg} / \mathrm{dl}$ in the second and third trimesters respectively. Relative to serum total vitamin $C$ concentration in the controls $(3.15 \pm 0.13$ $\mathrm{mg} / \mathrm{dl})$ these values are significantly lower $(p<0.05)$.

Conclusions: low serum vitamin $C$ in pregnancy may indicate utilization of this vitamin to mop up the excess reactive oxygen species and maintain its normal homeostasis. Therefore, Vitamin C supplementation during pregnancy is recommended in order to boost the body's low vitamin $C$ level and prevent the predisposition to low birth weight babies, premature delivery and pre-eclamsia all of which are known to be associated with sub-optimal vitamin C levels during pregnancy.
\end{abstract}

Key words Pregnancy, Vitamin C, Reactive oxygen species

\section{Resumo}

Objetivos: a concentração sérica total de vitamina $C$ (ácido 1-ascórbico) foi medida em 90 mulheres grávidas sendo 30 em cada trimestre (idade de 18-35 anos) e um grupo controle, pareado por idade, de mulheres não grávidas.

Métodos: a concentração sérica total de vitamina $C$ foi medida usando o método 2.4-dinitrofenilhidrazina que envolve a conversão de vitama $C$ a ácido dehidroascorbico na presença de íons cobre II e, em seguida, medindo a resultante bi-hidrazona em $540 \mathrm{~nm}$.

Resultados: a concentração total de vitamina $C$ no primeiro semestre foi de $2.55 \pm 0,13 \mathrm{mg} / \mathrm{dL}$ ) e de 2,32 \pm $0,40 \mathrm{mg} / \mathrm{dL}$ e 0,77 $\pm 0,10 \mathrm{mg} / \mathrm{dL}$ no segundo e terceiro trimestres, respectivamente. Estes valores são significativamente mais baixos do que nos controles $(3,15 \pm 0,13$ $m g / d L)(p<0,05)$.

Conclusões: reduzida concentração de vitamina $C$ sérica na gestação pode indicar a sua utilização para retirar o excesso de espécies oxigênio-reativas e manter a homeostase normal. Assim, recomenda-se a suplementação de vitamina $C$ na gestação para aumentar o seu baixo nível no organismo e previnir a predisposição para o baixo peso ao nascer, parto prematuro e pré-eclâmpsia, condições associadas a níveis sub-ótimos da mesma na gestação.

Palavras-chave Gravidez, Vitamina C, Mulheres, Espécies de oxigênio reativas 
Pregnancy is typically characterized by dynamic changes in multiple body systems, leading to an increase in basal oxygen consumption and changes in energy substrate use by different organs, including the fetoplacental unit. ${ }^{1}$ From early pregnancy, the placenta influences metabolism, particularly energy homeostasis. ${ }^{2}$ It imposes a heavy demand for metabolic energy, leading to an increased requirement for oxygen ${ }^{3}$ and an elevation in maternal basal metabolic rate (BMR) due to enhanced work with respect to maternal circulation, respiration, renal function and increased tissue mass. ${ }^{4-5}$ To meet this increased energy requirement during pregnancy, the human placenta is highly vascularized and sufficiently exposed to high maternal oxygen partial pressure. 6 The consequent accelerated intake and utilization of oxygen and the increased activity of the mitochondrial electron transport chain leads to the generation of high levels of reactive oxygen species (ROS) and an accompanying elevated level of oxidative stress. 7 Numerous evidence abound confirming the excessive production of reactive oxygen species and other reactive species during both normal and abnormal pregnancy.8-9 Morris et al.10 reported high circulating levels of lipid peroxides in normal pregnancy and pre-eclampsia. Similarly serum levels of other products of lipid peroxidation such as conjugated diene double bonds, fluorescent chromolipids and thiobarbituric acid reactive substances were found to increase in pregnant women.2,11-12 Also indicators of nitrogen-derived reactive species such as Snitrosoalbumin and S-nitrosothiols were found to increase during pregnancy, particularly in preeclampsia. ${ }^{13-15}$ Because of the abundance of reactive oxygen species during pregnancy, this work was aimed at measuring the serum concentration of total vitamin $C$ in the three trimesters of pregnancy considering the important role of this vitamin in the scavenging of reactive oxygen species and maintenance of healthy pregnancy.

\section{Methods}

The subjects enrolled in this study comprised 90 pregnant women, all attending the Antenatal Outpatient Pediatric Department (OPD) of the Department of Obstetrics and Gynecology, Bauchi State Specialist Hospital. The 90 subjects comprised three groups of 30 individuals per trimester and characterized as having low risk, uncomplicated pregnancy. All the study subjects were within the age range of 18-35 years. Exclusion criteria included diabetes mellitus, pregnancy toxemia, hypertension, asthma, renal disease and cancer. 30 age and agematched non-pregnant adult females were also enrolled for comparative control studies.

Assay for serum vitamin C. Serum L-ascorbic acid was assayed using the 2, 4-dinitrophenyhydrazine method which measures total vitamin $\mathrm{C}$ concentration by oxidizing all vitamin $C$ vitamers to dehydroascorbic acid in the presence of copper ions and subsequent measurement of the dehydroascorbic acid-bis-hydrazone derivative at 540nm. 16

The study was conducted in compliance with the Declaration on the Rights of the Patient. 17

Data are presented as mean \pm SEM. Data analysis was done using the Minitab-10 Statistical Software. Mean serum vitamin C concentration among trimesters was compared using One-Way ANOVA. The method of Least Significant Difference (LSD) was used to assess for significant differences between means after the ANOVA; $p$ values $<0.05$ were considered significant.

\section{Results}

Total serum vitamin $\mathrm{C}$ concentration in the three trimesters of pregnancy (mg/dl).

The results obtained are shown in Table 1. The mean serum concentrations of vitamin $\mathrm{C}$ in all the three trimesters were lower than the control. Average total vitamin $\mathrm{C}$ concentration in the first trimester was $20 \%$ less than the control vitamin $\mathrm{C}$ concentration of $3.15 \pm 0.13 \mathrm{mg} / \mathrm{dl},(p<0.05)$. Total vitamin $\mathrm{C}$ concentration in the second trimester was $26 \%$ less than the control concentration $(p<0.05)$. The largest decrease was found in the third trimester, with a $75 \%$ drop relative to the control serum total vitamin $\mathrm{C}$ concentration $(p<0.05)$.

\section{Table 1}

Total serum vitamin C concentration in the three trimesters of pregnancy $(\mathrm{mg} / \mathrm{dl})$.

\begin{tabular}{ll}
\hline Trimester of pregnancy & $\overline{\mathrm{X}} \pm \mathrm{SEM}^{*}$ \\
\hline First Trimester & $2.55 \pm 0.82^{* *}$ \\
Second Trimester & $2.32 \pm 0.40, * *$ \\
Third Trimester & $0.77 \pm 0.10^{* *}$ \\
Control & $3.15 \pm 0.13$ \\
\hline
\end{tabular}

* $F(3,116)=48.33(p<0.001) ; * * p<0.05$ (comparisons with control). 


\section{Discussion}

As noted earlier, human pregnancy is associated with increased requirement for dietary energy as a result of an elevated metabolic rate $^{3}$ due chiefly to increased oxygen consumption and subsequent utilization. The accelerated oxygen intake has been shown to lead to increased levels of oxidative stress via production of highly toxic reactive oxygen species. ${ }^{18}$ If left unchecked, reactive oxygen species inflict a constant barrage of oxidative damage to DNA, proteins and lipids.2,19-20 Evidence supporting this excessive reactive oxygen species production and accompanying oxidative stress during pregnancy include studies reporting low superoxide dismutase activity, low $\alpha$-tocopherol and increased serum concentration of products of lipid peroxidation such as thiobarbituric acid reactive substances (TBARS).6,11,21-22 The progressive decline in serum vitamin $\mathrm{C}$ concentration observed in this study could indicate an increased utilization of the vitamin by pregnant women to maintain normal reactive oxygen species homeostasis by using the vitamin to mop up the excess reactive oxygen species produced during the pregnancy state. This finding further supports earlier reports of reduced levels of antioxidant nutrients in pregnancy. ${ }^{23}$ Since the lowest serum vitamin $\mathrm{C}$ concentration was found in the third trimester, it indicates that oxidative stress is highest during this trimester of pregnancy. This therefore underscores the need for vitamin $\mathrm{C}$ supplementations throughout the entire period of pregnancy since mean serum vitamin $\mathrm{C}$ concentration in all the three trimesters are significantly lower than normal, control values. It also corroborates the clinical evidence for the unequivocal benefits of antioxidant supplementation to protect against excessive reactive oxygen species during pregnancy. ${ }^{7}$ Vitamin $\mathrm{C}$ supplementation is particularly important in pregnant women as its deficiency has been shown to affect placental structure and facilitates placental infection both of which results in increased risk of premature rupture of placental membranes and premature births.2,24 In addition the supplementation could help to prevent the development of such complications of pregnancy like gestational hypertension, intrauterine growth retardation and gestational diabetes, all known to be associated with high levels of oxidative stress, in addition to the numerous other benefits of this vitamin in human metabolism and health.25-26

\section{References}

1. Seis H. Oxidative stress II. In: Seis H, editor. Oxidants and antioxidants. London: Academic Press; 1991.

2. Casanueva E, Viteri FE. Iron and oxidative stress in pregnancy. J Nutr. 2003; 133: 5: 1700S-1708S.

3. Renata G, Miroslow K, Wlodizimierz K, Ryszard K, Ewa S. Changes in antioxidant components in blood of mares during pregnancy and after foaling. Bull Vet Inst Pulaway. 2002; 46: 301-5.

4. Lof M, Olausson H, Bostrom K, Janerot-Sjoberg B, Sohlstrom A, Forsum E. Changes in basal metabolic rate during pregnancy in relation to changes in body weight and composition, cardiac output, insulin-like growth factor I, and thyroid hormones in relation to fetal growth. Am J Clin Nutr. 2005; 81: 678-85.

5. Butte NF, Wong WW, Treuth MS, Ellis KJ, O'Brian SE. Energy requirements during pregnancy based on total energy expenditure and energy deposition. Am J Clin Nutr. 2004; 79: 1078-87.

6. Qanungo S, Mukherjea M. Ontogenic profile of some antioxidants and lipid peroxidation in human placental and fetal tissues. Mol Cell Biochem. 2000; 215: 11-19.

7. Agarwal A, Gupta S, Sharma RK. Role of oxidative stress in female reproduction. Reprod Biol Endocrinol. 2005; 3: $28-48$.

8. Agarwal A, Saleh RA, Bedaiwy MA. Role of reactive oxygen species in the athophysiology of human reproduction. Fertil Steril. 2003; 79: 829-43.
9. Agarwal A, Allamaneni SS. Role of free radicals in female reproductive diseases and assisted reproduction. Reprod Biomed Online. 2004; 9: 338-47.

10. Morris JM, Gopaul NK, Enderson MJ, Knight M, Linton EA, Dhir S, Anggard EE, Redman CW. Circulating markers of oxidative stress are raised in normal pregnancy and preeclampsia. Br J Obstet Gynaecol. 1998; 11: 1195-9.

11. Uotila J, Tuimala R, Aarnio T, Pyykko K, Ahotupa M. Lipid peroxidation products, selenium-dependent glutathione peorxidase and vitamin E in normal pregnancy. Eur J Obstet Gynaecol Reproduc Biol. 1991; 42: 95-100.

12. Moretti M, Philips M, Abouzeid A, Cataneo RN, Greenberg $\mathrm{J}$. Increased breath markers of oxidative stress in normal pregnancy and in pre-eclampsia. Am J Obstet Gynaecol. 2004; 190: 1184-0.

13. Tyurin WA, Liu SX, Tyurina YY, Sussman NB, Hubel CA, Roberts JM, Taylor RN, Kagan VE. Elevated levels of Snitrosoalbumin in pre-eclampsia plasma. Clin Res. 2001; 88: $1210-5$.

14. Shaamash AH, Elsonosy ED, Zakhari MM, Radwan SH, ElDien HM. Placental nitric acid synthase (NOS) activity and nitric oxide (NO) production in normal pregnancy, preeclampsia and eclampsia. Int J Gynaecol Obstet. 2001; 72: 127-33.

15. Henriksen T. The role of lipid peroxidation and oxidative lipid derivatives in the development of pre-eclampsia. Semin Perinatol. 2000; 24: 29-32. 
16. Kaplan LA, Pesce AJ. Clinical chemistry: theory, analysis and correlation. 2nd ed. Saint Louis: C.V. Mosby; 1989.

17. World Medical Association. Declaration on the rights of the patient. Available from: www.wma.net/e/policy/14.htm [2006 may 13]

18. Rao B, Sumita P, Roshrim MNA. Plasma antioxidant vitamins and lipid peroxidation products in pregnancy-induced hypertension. India J Clin Biochem. 2005; 1: 198-200.

19. Mohanty S, Sahu PK, Mandal MK, Mohapatra PC, Panda A. Evaluation of oxidative stress in pregnancy-induced hypertension. India J Clin Biochem. 2006; 1: 101-5.

20. Kamath U, Rao G, Kamath SU, Rai L. Maternal and fetal indicators of oxidative stress during intrauterine growth retardation. India J Clin Biochem. 2006; 1: 111-5.

21. Yoshika T, Ando M, Taniguchi K, Yamasaki F, Motoyama H. Lipoperoxidation and antioxidant substances in the human placenta during gestation. Nippon Sanka Fujinka Gakkai Zasshi. 1990; 42: 1634-40.
22. Chappell LC, Seed PT, Briley AL, Kelly FJ, Lee R, Hunt BJ, Parmar K, Bewley SJ, Shennan AH, Steer PJ, Poston L. Effects of antioxidants on the occurrence of pre-eclampsia in women at increased risk: a randomized trial. Lancet 1999; 354: 810-6.

23. Mikhail MS, Anyeagbunam A, Garfinkel D, Palan PR, Basu J, Romney SL. Pre-eclampsia and antioxidant nutrients: decreased plasma levels of reduced ascorbic acid, plasma tocopherol, and beta-carotene in women with preeclampsia. Am J Obstet Gynecol. 1994; 171: 150-7.

24. Romero R. Intrauterine infection, premature birth and the fetal Inflammatory Response Syndrome. J Nutr. 2003; 133 : 5: $1668 \mathrm{~S}-73 \mathrm{~S}$

25. Frei B, England L, Ames BN. Ascorbate an outstanding antioxidant in human blood plasma. Proc Natl Acad Sci USA. 1989; 86: 6377-81.

26. Rumbold AC, Crowther CA. Vitamin C supplementation in pregnancy. The Cochrane Database of Systematic Reviews 2005; 1: CD004072.

Submitted on September 9, 2005

Final version resubmitted on July 31, 2006

Aproved on August 8, 2006 